\title{
Multilateral cooperation for literacy promotion under stress: governance and management issues
}

\section{LESLIE J. LIMAGE *}

*The views expressed in this paper are solely the author's responsibility

\begin{abstract}
No face which we give to a matter will stead us so well at last as the truth. This alone wears well. For the most part we are not where we are, but in a false position.... Say what you have to say.... Any truth is better than make-believe.... I do not say that John or Jonathan will realize all this; but such is the character of that morrow which mere lapse of time can never make to dawn. The light which puts out our eyes is darkness to us. Only that day dawns to which we are awake. There is more day to dawn. The sun is but a morning star.
\end{abstract}

Henry David Thoreau, (1854), Walden

\begin{abstract}
This paper analyses recent organisational change and governance in the United Nations Educational, Scientific and Cultural Organization (UNESCO). The Organization has given priority to the promotion of universal literacy since its inception in 1946. It has persisted in its dual approach to universal literacy through both universal primary education and literacy learning opportunities through formal provision and non-formal learning opportunities for adults and out-of-school youth. A major policy shift in 2006 to abandon systematic and programatic concern for literacy at UNESCO Headquarters drastically changed priorities. That decision is analysed in the broader United Nations (UN) system setting, United States' policies since its return to UNESCO, and the recent internal governing dynamics of the agency.
\end{abstract}

\section{Introduction}

Universal literacy promotion has been on UNESCO's priority agenda for sixty years. Over time, the strategies promoted to reach literacy for all have varied with political will, financial resources and various development or economic growth models. Essentially, whether UNESCO saw itself as an intellectual cooperation agency with a holistic sector-wide approach to education or, on occasion, as an operational development partner conducting projects, programs or providing technical advice, literacy was promoted as human right and public responsibility (Limage 1987, Limage 1993, Limage 
2005a, Jones 1988; 2005). This approach has taken into account the historical development of literacy (Graff 1987, Limage 2005a, Vincent 2000).

After 1990 United Nations International Literacy Year, literacy, particularly for adults, received little international attention, notably, as I and others have argued, because of the push for universal primary education at the World Conference on Education for All (WCEFA). Priority for primary education by the WCEFA partners, especially the World Bank and the United Nations International Children's Emergency Fund (UNICEF), led to UNESCO decreasing its own commitments to adult literacy (Rausch 1995, Limage 1999, Jones 2005). The Dakar Forum on Education for All (2000) provided the possibility to reinvigorate multilateral and bilateral attention to both universal primary education and adult literacy with the six Education For All (EFA) goals. UNESCO was declared the lead coordinating agency for Dakar Follow-up. The creation of the independent EFA Global Monitoring Report (due to funding primarily by the British Department for International Development) to monitor agency and country commitment and progress towards those goals also promised to re-focus attention on literacy. Indeed, the EFA Global Monitoring Report: Literacy for Life 2006 came out with a three-pronged approach summing up the best available research and policies to achieve this Dakar goal. It built on the classic UNESCO two-pronged approach with a third dimension, the creation and maintenance of literate environments. Those recommendations echo the criteria for sustained attention to literacy and recommendations I put forward in the 'Background and issues paper on literacy for empowerment' for the Working Group on EFA in July 2005 (Limage 2005b)

However, in June 2006, in the latest re-organisation of the UNESCO Education Sector, substantive system-wide attention to literacy was to be practically eliminated from the UNESCO Headquarters program. For the first time in sixty years, the only international specialised UN agency with a consistent commitment to literacy was planning to re-configure that priority, decentralising its substance to an institute with varying commitment in regional offices and re-focusing UNLD coordination on follow-up conferences after the First Lady of the United States event of 18 September 2006 in New York. In the $175^{\text {th }}$ Executive Board in October 2006, many major developing countries expressed their disagreement with this change. The Board adopted consensus decisions: (a) calling for an External Auditor investigation of the financial arrangements for the consultant-led process; (b) requesting that the Director-General refrain from taking major structural and senior management decisions without first consulting them as required by the UNESCO Constitution; and (c) asking for a more credible EFA Global Action Plan (UNESCO 2006c) In the $176^{\text {th }}$ Executive Board, the Member 
States received and discussed the External Auditor's report which had been made public. The Assistant Director-General for Education had already given his resignation, publishing his letter in California press (Smith 2007) and departed immediately after its submission on 12 March 2007 at the request of the Director-General.

This paper, as with my earlier article (Limage 2007), provides a preliminary analysis of events and the impact on literacy promotion through multilateral cooperation. It is immodest for an actor in UNESCO's recent organisational and substantive history to consider herself dispassionate. However, this paper may contribute to a more clear-eyed look at how to advance the best of multilateral action in the field in which $I$ have been involved at all levels throughout my adult life: children's and adults' literacy worldwide.

I continue to argue that ill-conceived 'reforms' take place in UN institutions such as UNESCO because of lack of commitment to the basic systemic management mechanisms forcefully explained in the Independent Inquiry Committee report on UN management of the Iraq Oil for Food Programme (IIC-OFFP) Report in 2005 with respect to UN agencies' management of the Iraq Oil for Food Programme. While that Programme's management within UN agencies provided the greatest example of systemwide lack of transparency and accountability, it is by no means only relevant to these agencies' actions in humanitarian, conflict or reconstruction settings. Indeed, as early as 1988 Jones refers, in his first book on UNESCO and literacy, to the neglect of professionalism in staffing matters in its Education Sector as a major reason for the decline of serious attention to literacy. While he did not foreshadow the grave current issues, he did see the early stages of a trend.

\section{Recent institutional history of attention to literacy: United Nations Literacy Decade}

The United Nations Literacy Decade (UNLD) went largely unnoticed worldwide after its 2003 launch. While UNESCO had set up an independent United Nations International Literacy Year Secretariat staffed by international literacy experts in 1989 in preparation for the year-long mobilisation, it did nothing of the sort for the Decade. As a result, UNESCO was in no position to take advantage of accumulated knowledge and expertise within the Organization or in the international community. It did not develop a vision and strategy commensurate with the level of sophisticated literacy advocacy or promotion expected of an agency with sixty years' experience of literacy provision in schools and adult learning opportunities. When the Education 
Sector reported to the Executive Board on progress with the UNLD Plan of Action, it was found to be seriously in need of reinforcement. The 172nd Executive Board called on the Sector to make greater effort:

... requests the Director-General to strengthen the Organizationwide commitment to literacy for all age groups, and ensure concerted, sustainable action with its field offices and specialized institutes, as well as UNESCO partners to successfully achieve the United Nations Literacy Decade goals... (UNESCO 21 November 2005c).

The UNESCO Secretariat document for which it is the decision stated:

... it is evident that there is a strong need for a clearer sense of direction and purpose with a sustained program of intervention as is vital to a decade-long effort. ... In order for UNESCO to fulfill its mandate with respect to the ambitious goals of the UNLD, it requires a sustained commitment in terms of human and financial resources. UNESCO has had some 50 years' experience in bringing literacy for all age groups onto the international agenda. It needs to better harness that experience and the lessons learned to give the UNLD the foundation, infrastructure and flexibility to provide the sustained and quality services expected by Member States... (UNESCO 2005a).

This was an intentionally crafted plea (by this author) that UNESCO build on its own experience at the time.

When I drafted the second UNLD Progress Report to the UN General Assembly for the period 2005-2006 in the Spring 2006, the situation remained challenging. The report reflects that lack of mobilisation within UNESCO and in Member States. Firstly, UNESCO requested Member States to reply to a questionnaire regarding their action to promote literacy during the 2005-2006 period. Unfortunately, the questionnaire lacked clarity in conception and only referred to non-formal education, policy change and research to solve 'problems'. It was not a systematic source of information. However, I wrote on behalf of UNESCO in the report to the UN General Assembly: ' there is a strong case for reviews of the history of literacy policies and legislation for individual countries and international organizations so that 'change' is based on evidence-based experience and that sustainable policies lead to concrete identifiable results' (UNESCO 2006a). The rest of the UNLD Progress Report recalled the challenges to the effective promotion of 
a fully literate world, the level and range of resources required and major recent recommendations.

Immediately after I submitted this report to UN Headquarters in New York through bureaucratic channels, a major re-structuring or 'reform' of the Education Sector took place that abruptly ended my own work and that of many of my colleagues. In order to understand these changes concerning structure and substance (literacy in particular), it is essential to have some background about UNESCO's political context.

\section{Political stress for UNESCO: United States withdrawal and return}

The United States withdrew from UNESCO in 1984 and returned in October 2003. The nature of that withdrawal and return are particularly relevant to this discussion. Just as the United States withdrew from UNESCO in 1984, the Organization was beginning to give attention to literacy issues inindustrialised countries as well as developing ones. As I joined the International Literacy Year Secretariat in 1989, literacy in industrialised countries was made part of that UN year. Although all UN years and decades are intended to cover all countries, that is sometimes forgotten. In this instance, although the United States had officially withdrawn from UNESCO, the United States Observer at the time funded a bilingual literacy expert to the International Literacy Year (ILY) Secretariat. There was also intensive governmental, research community and practitioner participation in ILY activities. Throughout the period of official United States absence, there was continuous cooperation with American partners in UNESCO activities, particularly with respect to literacy.

Over the years, there had been a strong professional and political movement within the country to promote its return. That return seemed imminent in 2002. However, the announcement by President Bush of the actual return on 12 September 2002 in a speech at the UN General Assembly, primarily devoted to concerns about the war on terrorism, was unexpected (Bush 2002). Apparently, the United States Observer Mission to UNESCO was not informed ahead of time, nor was most of the United States State Department. It appeared that the decision was made in the White House and in the context of his war on terrorism.

When President Bush announced United States return, he did not immediately mention literacy. However, the return arrangements reached between the President and UNESCO included the designation of the First Lady, Mrs. Laura Bush, as Honorary Ambassador for the UNLD. The First 
Lady had a longstanding commitment to education, to promotion of the reading habit among young children and mothers. She shared that concern with the former First Lady, Mrs. Barbara Bush. So, the White House, the State Department and UNESCO formed a special relationship early on with respect to literacy. Since the UNLD was officially launched in 2003 and the United States returned officially in the last quarter of that year, there was a unique opportunity to have a formative effect on the Decade. As UN agencies actively seek the advocacy provided by well-known personalities, the designation of the First Lady as Honorary Ambassador, was met with considerable satisfaction.

Early on and quite understandably, the White House was concerned that the First Lady play an active role in literacy advocacy worldwide, particularly in concrete situations. The Director-General responded by calling on the Education Sector to develop three major initiatives, one of which became the Literacy for Empowerment Initiative (LIFE), so that highly visible literacy promotion would be seen to be taking place. The United States Ambassador to UNESCO was conveying proposals from the White House for such activities and their management location. The Division of Basic Education's Adult Literacy and Non Formal Education Section maintained nominal responsibility for both the UNLD and the emerging LIFE initiative until July 2006. An early concern of the United States administration was definitely to encourage literacy through the First Lady's advocacy as UNLD Honorary Ambassador. However, there was no overall policy strategy for the United States return to UNESCO. Its financial contribution to UNESCO for the period October-December 2003 (15 million dollars) was designated at that country's request for education and rehabilitation of cultural heritage in post-conflict settings.

Furthermore, the United States took a strong position against the proposed Convention on the Protection and Promotion of the Diversity of Cultural Expression (adopted October 2005). Throughout 2004 and up until the UNESCO General Conference of 2005, the major United States priority seemed to be to prevent UNESCO from adopting such a normative instrument, seeing it as outside UNESCO's mandate as primarily a trade issue, and highly politically-charged. During the 2005 General Conference, the United States called for a vote on its adoption as a Convention. It proceeded, for the first time in UNESCO history, to call for a vote on the 2005-2006 program and budget. However, on the whole, the initial United States return to UNESCO was taken based on a close dialogue with the Director-General and on the official position that he had successfully addressed most of UNESCO's systemic management problems that had led 
to the United States withdrawal eighteen years earlier (White House Statement 2002).

\section{Management stress: The Independent Inquiry Committee report on UN management of the Iraq Oil for Food Programme}

Neither the United States government nor the UN had been faced with the Independent Inquiry Committee Report on UN agency management of the Iraq Oil for Food Programme at this stage (IIC-OFFP 2005). None of the nine specialised agencies of the UN, including UNESCO, had been reminded of systemic management shortcomings. The United Nations Headquarters in Baghdad had not yet been bombed as it was on 19 August 2003, bringing an end to illusions that it was viewed as neutral in the implementation of sanctions.

The Iraq Oil for Food Programme was conceived to allow the UN to supervise the sanctions imposed on Iraq after the first Gulf War and invasion of Kuwait in 1991. It was intended that Iraq use oil revenue to purchase humanitarian aid so that the Iraqi people not suffer from the effect of those sanctions. The UN agencies' role was to monitor the purchase and distribution of that aid. In other words, it was essentially a procurement program and fully outside the mandate and core functions of agencies like UNESCO. The entire Programme was thus flawed from the outset in terms of the capability of specialised agencies to carry it out and especially, in terms of the lack of agency internal safeguards for accountability, transparency, professionalism and timely action.

The IIC published its Volume IV on UN agencies' management of the Programme and its follow-up through 2003 on 7 September 2005. The Report recalls that 'the tone starts at the top'. It lays out the systemic mismanagement by $\mathrm{UN}$ agencies and points out the directions in which the agencies would need to go to conduct full-scale internal investigations and inquiries. The IIC explains that they were not able to conduct all those investigations themselves for a number of reasons that include: (a) lack of full cooperation by the agencies' staff; (b) conditions in Iraq following the United States invasion and (c) the scale and complexity of the mismanagement due to lack of basic good governance and accountability mechanisms in each of the agencies.

The Report clearly states that, where they illustrate specific aspects of mismanagement and the nature of UN agency work in corruption-prone environments, they are only indicative of the kinds of situations which arose 
rather than the full picture of 'wrongdoing' by any of the UN agencies. For example, in the section of the report on the problems that occurred when an agency worked outside its core mandate in an area for which it had no competence, the illustrative example for UNESCO is a 'chalk factory'. (IICOFFP 2005, Vol IV: 122).

The systemic management recommendations include: (a) recruitment of senior management with transparency, ethics investigations and professional criteria; (b) accountability of senior management; (c) obligatory conflict of interest and financial disclosure for all staff members at all levels; (d) effective whistleblower policies and protection; (e) ethics in management training and protection against cronyism in recruitment and staffing, among others. These recommendations also figured in the World Summit Outcomes Document in September 2005 and have been implemented progressively by UN Headquarters. However, although UNESCO Member States called for the Organisation to lay out an action plan for their implementation, that had not taken place by spring 2008. This was not due to lack of effort by the Internal Oversight Office. It appears rather to be due to a lack of commitment at the highest policy level of UNESCO to accept these systemic management safeguards for all of its work, financed from both regular and extra budgetary sources.

\section{UN-wide Reform and UNESCO's role in education}

Over the past ten years, especially since the Iraq Oil for Food scandal, the UN is attempting to develop system-wide coherence and effectiveness based on a rigorous review of mandates, duplication, and coordination problems. The harassment, corruption and gender-based violence of certain UN peacekeepers have also contributed to this conscience searching. It has been suggested that the UN focus on the environment, development and humanitarian assistance. It is not clear how UNESCO will position itself with respect to its current mandate in education, natural sciences, social sciences, culture and communication. The UN has been reviewing its mandate in all its sectors since 2006: natural and social sciences, culture and the independence of the World Heritage Committee, communication, as well as education. This paper focuses primarily on the third 'reform' of its Education Sector in a six-year period and aftermath. Since 2000, the Director-General has presided over three re-structurings of the Education Sector that are called 'reforms'. 


\section{Organisational stress: the fate of literacy at UNESCO}

The recent Assistant Director-General for Education, Mr. Peter Smith (June 2005), arrived with a mandate to improve management and effectiveness to promote Education for All. He engaged an American consultant company to carry out a diagnosis of the Education Sector with contracts, over 2005-2006, of 2.2 million dollars. He announced a restructuring of the Sector on 21 June 2006, which came as a surprise to most staff members. The details of the re-structuring were laid out in a DirectorGeneral 'Blue Note' (12 July 2006) and the senior management staffing decisions in another 'Blue Note' (27 July 2006), followed by others. In a thorough re-conceptualisation of UNESCO's education priorities under a 'matrix' approach, substantive attention to education was confined to two of the six divisions at Headquarters. The others became essentially administrative. The former Division of Basic Education had included early childhood education, inclusive education, primary education and adult literacy/non formal education. It was reduced to cover certain general themes of formal education such as 'quality' and 'values'. It excluded adult and continuing education as well as adult literacy. Indeed, literacy was no longer the purview of UNESCO Headquarters. The substantive and policy work for literacy was to be handled by the UNESCO Institute for Lifelong Learning (former UNESCO Institute for Education (UIE) in Hamburg). The United Nations Literacy Decade was transferred to a division for United Nations priorities. The UNLD was staffed by two junior professionals. It was also to include the management of the UNESCO literacy prizes as well as International Literacy Day celebrations, two major UNESCO literacy advocacy tools over more than thirty years. The UNLD programs were refocused as support or follow-up to the First Lady conference held in New York on 18 September 2006 (United States State Department 2006). Indeed, the UNLD coordination at UNESCO was re-focused to carry out four regional follow-up conferences to this event. Other programmed activities were cancelled. The Adult Literacy and Non Formal Education Section was disbanded. The various staff were informed that they were to be re-located for unspecified functions in field offices around the world.

It may have been argued that the re-organisation of the Education Sector as a 'matrix' organisation would in time provide a more flexible approach to changing UNESCO and Member State priorities. On the other hand, if literacy (meaning basic reading, writing and numeracy skills and competencies) is no longer handled visibly, systematically and holistically at Headquarters-level, it is unlikely that specific institutes or field offices would be able to provide agency policy and coordination in its stead. Already, as I wrote in 1999 (Limage 1999), when adult and continuing education was 
removed from UNESCO Headquarters some nine years earlier to the UIE Hamburg, adult literacy was weakened conceptually. I argued that adult literacy was treated outside the most marginalised form of education, mainstream adult and continuing education, and that it would be reduced to non-formal provision. That indeed became the case for the next six years at UNESCO Headquarters. The section within the Division of Basic Education saw its purview to be primarily non-formal adult education. It has led to what may prove to be the further marginalisation of attention to adult literacy as well.

The Assistant Director-General for Education called an information session for Permanent Delegates on 25 July 2006 because of widespread concern about the re-structuring. Ambassadors representing the Africa Group, the European Union, Algeria, Pakistan and Venezuela, questioned the transparency, respect for procedures and advisability of the substantive change. Several expressed reservations about the fate of literacy, especially $\mathbf{E}$ 9 countries (countries with the largest populations and largest literacy needs). The $175^{\text {th }}$ Executive Board in October 2006 addressed the financial, organisational and substantive changes with concern. In addition to the request for an External Auditor investigation, one of the largest and most inclusive debates about literacy took place in an item on the Cuban literacy approach 'Yo si puedo'. Some thirty countries asked for re-assurance that the re-focusing of the UNLD around follow-up to the US First Lady event not lead to elimination of diversity in UNESCO's promotion of literacy learning approaches. (Observer records 25 June 2006)

\section{Organisational stress and political stress: $175^{\text {th }}$ and $176^{\text {th }}$ Executive Boards}

Since UNESCO is an intergovernmental organisation comprising 192 Member States, any serious analysis of how it addresses its problems must take into account its political dimension. The complex history of UNESCO is thus about individuals and their own decision-making or professional knowledge. It is even more about the governmental 'elites' of Member States who are moving forward various agendas and reaching a formal consensus that shifts over time. It is also about the larger context of the international aid architecture, its dominance by bilateral arrangements, as well as the credibility crisis of the entire UN system.

UNESCO is governed by its Member States meeting every two years in a General Conference and twice a year by 58 Member States meeting in its Executive Board. The Secretariat, led by the Director-General, implements the agreed program and budget. Both governing bodies have been lax in 
setting clear, well-defined priorities and in exerting strict management and fiduciary accountability. The case study in this paper illustrates the mixed messages that thus emerge, which in turn, allow the Secretariat to do nothing, or to make mere cosmetic changes, or to continue previous practice.

Further, decisions on specific matters tend to be taken by 'consensus', rather than by vote. Thus, all contentious issues tend to be negotiated outside the formal Board meeting room and reduced to a text that appears to have unanimous support. The 'consensus' decision-making is intended to show agreement on the way forward and generally calls for further reporting at a future session. Countries express reservations on occasion by requesting a statement to appear in the Summary Record.

During UNESCO's $175^{\text {th }}$ Executive Board (October 2006), many developing country representatives questioned the financing and the process of the re-structuring as well as the fate of literacy and Education for All international coordination. However, the United States and key European countries did their best to contain dissatisfaction. In spite of these containment efforts by 'developed countries', leadership by Algeria, Benin, India, South Africa and certain Latin American countries led to a consensus decision requesting investigation by UNESCO's External Auditor of the processes by which the Assistant Director-General for Education had hired an American consultant company for the Education Sector reform. The staff associations were also calling for respect for existing staff and finance rules. They were trying to ensure due process for staff members who had been removed from their functions or were the object of arbitrary sanction.

For example, the Indian Ambassador stated in her intervention to the $175^{\text {th }}$ Executive Board:

The ongoing reforms in the Education Sector are of great significance to us.... The reform process did not follow wellestablished UNESCO traditions of wide-based consultations.... The mandate for reform of the Education Sector as given out by this body at its $171^{\text {*t }}$ Session was tied to the better delivery of EFA Goals by UNESCO. Some of the reforms cannot be justified from the perspective of increasing UNESCO's commitment to EFA. On the contrary, ... UNESCO's continued focus on literacy and related issues is of paramount importance. The proposal to move literacy from within the Education Sector and make UIL, Hamburg responsible for this activity has serious implications. Such a fundamental change should not have been 
implemented without consulting the Board.... This reform should be rolled back. (Mukherjee 3 October 2006)

Professor Brian Figaji, the South African representative stated:

UNESCO, as the lead specialized agency for EFA, should vigorously reassert that lead role and ensure close co-ordination to avoid duplication of activities and marshal all available resources, human, financial, and technical, no matter how scarce they may be, in pursuit of this one shining objective. However, we are somewhat disturbed by the huge expenditure on consultants employed for the reform process. This cost has been incurred at the expense of the regular program... the way the decision was made and the money allocated leaves us with some serious concerns... (Figaji 3 October 2006)

During autumn 2006 and early winter 2007, the Auditors carried out their investigation. They provided their findings to the Director-General in January 2007. Senior management and certain countries tried to prevent the report from figuring in the Executive Board's $176^{\text {th }}$ session or, failing that, to prevent its findings from being discussed in open session. Nonetheless, the Auditor's report became a public document more than one month prior to the session. The principal finding was that UNESCO possessed perfectly adequate rules and regulations concerning the procurement of services. However, these rules were intentionally circumvented by the Assistant Director-General for Education. Furthermore, the Director-General did not have the authority to waive these rules. The Auditor reported that:

The power to grant waivers is a discretionary power, in that it is a question of the Director-General's appraisal of the matter, but it is not an arbitrary power (emphasis in the original) beyond the scope of any rule.... The case under consideration here falls within the scope of the Administrative Manual's provisions... (UNESCO 16 March 2007: 28)

The Auditor also found that the Education Sector Administrative Officer who tried to enforce respect for procedures was removed from his responsibilities for his efforts. The personal assistant of the Assistant Director-General for Education and the Deputy Assistant Director-General for Education took over those fiduciary responsibilities (UNESCO 16 March 2007: 13). The Legal Affairs Officer who tried to advise on proper 
procedures was also circumvented. (Thanks to his courageous testimony to the $175^{\text {th }}$ Executive Board, Member States could ask for the investigation). (UNESCO 16 March 2007: 1)

The public nature of the External Auditor's report meant that the nonrespect of procedures was well known. However, since the Director-General had ultimate responsibility for approving both the consultant contracts and the re-structuring and personnel decisions taken as a consequence, the response was more complex.

During the first follow-up conference to the First Lady of the United States event of September 2006 in Qatar on 12 March 2007, the matter came to a head between the Director-General and the Assistant Director-General for Education. The latter had published a letter of resignation dated 12 March 2007 in a California press website on 14 March stating that, due to 'death threats' and lack of support as well as 'demonization of the United States', he was offering his resignation to take place in June 2007 (Smith 2007). The Director-General announced on 15 March 2007 that in fact the resignation would take place immediately. He personally took over the Education Sector management.

Thus, at the time of the $176^{\text {th }}$ Executive Board in April 2007, the former Assistant Director-General for Education was gone. Since he had provided his own letter to the press, the issue was covered widely in major newspapers. The literacy event in Qatar at a follow-up conference did not have any international repercussions under the circumstances.

During the session, members spoke to these issues in the manner that characterised their handling of management and substance. The DirectorGeneral committed to follow recommendations to strengthen UNESCO procedures. However, he asked members to help advance his reforms, as any backsliding at this stage would jeopardise the momentum already gained:

The ED Sector Reform has enabled the sector to realign its work in accordance with the priorities and needs identified through the GAP [Global Action Plan] and UNESS [UNESCO National Education Support Strategyl processes.... the recent resignation by Peter Smith, the Assistant Director-General for Education, will in no way affect the basic direction taken by the Education Sector Reform, whose implementation will proceed. (UNESCO 16 April 2007) 
The United States Ambassador, Mrs. Louise Oliver, took the same position:

...the process of reform is not an easy one, particularly in an intergovernmental organization...Recent reforms made in the (Education) sector should strengthen its ability to carry out its responsibilities...Even though there are concerns relating to the External Auditors' Report, the sector must continue to focus on its important initiatives, and maintain the reforms that are starting to show results... (Oliver 18 April 2007).

Mr. Einar Steinsnaes, the Norwegian representative, supported her position (as they had also supported the 'reform'):

- the Director-General bears the responsibility and must make every effort in revising rules and regulations according to the recommendations from the External Auditor and ensure that they are practiced;....the reform of the Education Sector must continue in order not to lose the momentum gained....The Audit Report and other related evaluations must not be used as an argument for delaying the EFA progress and the reform process (Steinsnaes 17 April 2007).

The U.K. Ambassador Peter Landymore followed suit:

...We are at a critical juncture....We should all welcome the swift and comprehensive response that the DG has given. The process of reform and restructuring has been, inevitably, difficult. The last thing we should do now is falter, or - least of all - reverse its progress. The best interests of the poorest countries, especially in Africa.....are best served by pressing forward the change process... (Landymore 18 April 2007)

However, the Indian representative, Dr. Kapila Vatasyayan, took a critical stance:

Since the last meeting of the Board, there have been several important developments of far-reaching implication to the Organization... It is disturbing to learn that there has been a lack of transparency and accountability in respect of what has been termed as the whole process of 'Reforms in the Education Sector'... I have been told that those who had the courage to 
point this out at that time were removed from their positions and sent to perceived punishment postings...Those who questioned the process at that time were told that they were 'against reform'. I hope that you will not accuse me of the same when I say that the time has come to take a pause.... Taking stock and changing course is not a sign of cowardice. It is only the strong, who acknowledge the need to change course when required (Vatasayan 18 April 2007).

Prof. Brian Figaji, the South African representative, who had also called for the investigation in the previous session, stated:

In respect of the External Auditors' report on the procurement of services in the Education Sector....the South African delegation found that the audit had not gone far enough...

However.... we need to look ahead... and strengthen the hand of the DG so that he can put the structures and processes in place to heal this ugly wound.... I cannot leave this matter without making a very special appeal to the DG about the unfair treatment meted out to those who chose to blow the whistle or who would not cooperate with the implementation of the irregularities.... Your response to this matter DG should send a strong message to this organization that whistle blowing will NOT result in punishment. This is your responsibility as the DG and I trust that you will do what is right and just. (Figaji 18 April 2007)

The Ecuador representative, Mr. Juan Cuevas, was equally incisive:

Regarding the Education Sector reform, my Delegation wishes to state how much it deplores non-respect of the Organization's rules concerning procedures for recruitment of consultants.... There can be no tolerance for such actions which can seriously endanger the legal security and transparency of the Organization. Impunity in this matter carries the seed of the destruction of our Organization. The responsible parties should be severely punished and the mis-used funds should be returned to UNESCO. (Cuevas 18 April 2007)

The Portugal representative, Mr. Ramalho Ortigao, speaking on behalf of the European Union, provided the inevitable mixed message conveyed in such consensus statements. He states: 
The reform of the Education Sector remains of vital importance for the Organization. The regrettable facts the audit report has outlined must not be allowed to compromise the reform.... . But later he contradicts himself - the information provided about this reform has been scarce. We would have welcomed a more informative, well-documented report to the Executive Board by the Director-General on the state of the reform and UNESCO's educational policy. (Ortigao 18 April 2007)

These positions summarise Member States' responses to the Auditors' investigation. The Auditors regularly verify UNESCO's accounts for each biennium. They are not normally called upon by the governing bodies in this manner (although that is not to say that they should not have been called upon earlier). The United States, Japan and European countries took the position that the unfortunate situation should be forgotten and not jeopardise the pace of the Education Sector reform. The United States and the United Kingdom representatives warned that any vulnerability in this respect would serve forces in their respective countries that might call for withdrawal from UNESCO again. They brought other spectres to bear on individual country representatives who had spoken up, or who might influence those who were likely to do so (Observer interviews).

Mr. Philippe Séguin, the External Auditor, presented his report to the $176^{\text {th }}$ Board. He summarised his conclusions:

iii ... I insist on the fact that at no place in our report do we affirm that the non-respect of regulations regarding the Education Sector contracts was the result of weak procedures. That would be the opposite of the truth to interpret the report in such a manner. The simple truth...is the Assistant Director-General for Education, who took the initiative and therefore the responsibility to pass contracts with a firm without respecting the Organization's rules, did so in full knowledge of what he was doing.... The advisability of taking the Education Sector forward on the basis of existing diagnostic studies and the internal expertise already available was not even considered .... it is up to the Director-General to hear our message and act consequently. In this respect, I think that it would be inadmissible that people who pointed out irregularities should suffer or be sanctioned in their professional advancement (Séguin 23 April 2007). 


\section{The Executive Board response}

UNESCO governing bodies take positions about events, reports, and issues presented to them or raised by themselves on the basis of 'Draft decisions' that are usually prepared in advance by the Secretariat. However, many country delegations propose amendments to these 'Draft decisions' or propose entirely new ones. These decisions are almost always adopted by 'consensus'. In this instance, several developing countries (Algeria, Benin and India) proposed a 'Draft decision' including a call for disciplinary action against those involved in the financial or managerial wrongdoing. They also asked that staff who had been sanctioned or adversely affected by the irregular re-structuring and financial processes be re-instated (UNESCO 17 April 2007). However, the United States, Japan and certain European countries prepared another 'Draft decision,' which only called upon the Director-General to strengthen and enforce regulations. They worked to ensure that there would be no accountability for wrongdoing concerning the Education Sector 'reform'. They were successful. An article by Colum Lynch in the 6 May 2007 issue of the Washington Post, sums this up journalistically: 'US Fights off bid to punish UNESCO official'.

Nonetheless, the Education Sector reform was not the only major issue that came before the $176^{\text {th }}$ Executive Board. Members did not accept any of the Director-General's proposals regarding the next biennial budget, nor was any recommendation approved concerning the re-organisation of the other Sectors. UNESCO thus needed to address its most pressing long-term problems at future sessions.

As a result of the polarisation of political positions, special interests, confusion about the outcomes expected by the Board from the DirectorGeneral, lack of a clear message concerning the kinds of behaviour expected of regular staff members and senior management, a climate of continuing uncertainty prevails in UNESCO. This uncertainty began for staff on the $21^{\text {tt }}$ June 2006 when many Education Sector staff had their professional responsibilities taken away without others foreseen. Some ten senior professionals were particularly targeted for elimination in one way or another. A new Assistant-Director General named in September 2007, the former Director of the EFA Global Monitoring Report, was charged with revitalizing the Sector. The changes he had made by March 2008 included bringing the EFA coordination under his direct supervision and recruiting two Norwegianfunded directors to take charge under him. He effectively prolonged the ambiguity of financial and human resource controls in the Education Sector (DG/Note/08/08, 4 March 2008). 
The potential operation of the UNESCO Education Sector outside the overall Organization-wide financial and management controls was not lost on the External Auditor or certain Board members at its $179^{\text {th }}$ Session in April 2008. The latter were not convinced by the Director-General's presentation of the matter as one of 'experimental decentralization'.

Mr. Séguin reported on the follow-up to his earlier recommendations:

The new position and necessary independence of Administrative Officers is not yet a reality. And that is totally regrettable. The daily functioning of the teams responsible for internal control in the sectors, institutes, and field offices has not changed significantly either.... We consider it necessary to end the current procrastination because it is urgent to do so... Failing this, the Organization will not be safeguarded against further accidents along the lines of the one we previously examined in depth. (Séguin 11 April 2008)

Professor Brian Figaji, South African Board member, referred to the lack of 'consequence management'. He later remarked:

This audit was brought about by the problems in Education and I would imagine that the repair should be focused on Education but unfortunately the Education Sector just cannot undo the errors of the past and correct the staff structure to represent the Administrative Officer as required by the Auditors... So, Mr. DG you have accepted the External Auditor's report which requires a particular reporting line for the Administrative Officer and you support the Education structure which contradicts the External Auditor's requirements... The argument that there is sufficient segregation of duties for a decentralized organization is not good enough... (Figaji 7 April 2008: 3-4).

Similar positions were taken by Algeria, Cuba, India, Sri Lanka and Tanzania. On the other hand, the United States, like the other European members, made no reference to the critical state of the Education Sector management and its relation to effective program conception and delivery. Instead, Oliver pointed to vague 'progress' in the area of literacy promotion:

Unfortunately, instead of fulfilling its role as the UN's lead voice in education, UNESCO increasingly focuses on issues already being dealt with by other specialized UN agencies....When UNESCO does focus on one of its priorities, progress can be made, such as has occurred in the area of literacy, thanks to 
UNESCO's LIFE initiative and its regional literacy meetings.

We hope that literacy will continue to be a priority for UNESCO after the last two regional meetings are held in Azerbaijan and Mexico... (Oliver 8 April 2008).

The UNESCO External Auditor continued to report on the fact that the Education Sector remained outside his recommendations for independent financial controls as recently as the 181" UNESCO Executive Board in March 2009 (UNESCO 24 March 2009). No explanation was provided by the Director-General or the Assistant Director-General for Education as to why that should be the case. At the same time, however, an effort was made to bring part of the literacy program back to Headquarters, that is, the LIFE initiative. The case was made that international coordination and technical services worldwide were best provided from Headquarters rather than from the small UIL in Hamburg. Political pressure from Germany and certain other countries opposed the move. As UNESCO prepares to elect a new Director-General in autumn 2009, and the Assistant Director-General for Education resigned in July, the fate of literacy, indeed of the growing recognition that UNESCO should treat the entire education system as a whole once again, remain on the unfinished agenda. The emphasis on the donor-driven EFA coordination to the detriment of higher education and secondary education is beginning to be recognised. This was clearly the case at the July 2009 World Conference on Higher Education (UNESCO 8 July 2009).

\section{Stress for multilateral cooperation for literacy at this time}

I again raised the intertwined issues of substance, politics and management. It has long been my professional experience that no sustainable progress can be made outside a highly ethical management context. This is even more critical for a UN agency composed of 192 governments with divergent special interests and political agendas. The entire UN system has been under pressure. UNESCO's broad mandate lends itself to being more susceptible to those pressures. On occasion, it has risen to the challenge due to a fortuitous mix of outstanding intellectual and moral leadership alongside a modesty of claims. On other occasions, when its leadership has acted more on the basis of short-term political expediency, its professional staff struggles to provide continuity of service to UNESCO's goals. However, without an independent, neutral and highly qualified professional international civil service, free from such pressures, UNESCO will continue to founder.

My concerns for literacy are crystallising. The $177^{\text {th }}$ Executive Board document on the progress of the UNLD coordination was a clear indicator (UNESCO 3 August 2007). As the UNESCO staff author of the earlier two 
Executive Board reports as well as the report to the UN General Assembly presented in September 2006, I am probably more sensitive to what does or does not go into such documents, as well as to bureaucratic understatement and caution. The Progress Report for 2006-2007 stated that it presents 'highlights' of the document submitted to the UN General Assembly. In fact, it does something quite different. It 'highlights' the White House Conference on Global Literacy held for a half-day in New York by First Lady Mrs. Laura Bush on 18 September 2006. It then re-focuses the rest of the UNLD as follow-up to this event through reference to the next conferences. The other critical considerations in the UN General Assembly report or in earlier reports to UNESCO's own Executive Board are absent. Indeed, one has the impression that UNESCO suffers from severe amnesia and that nothing has taken place previously upon which to build other than the White House Conference:

Given the relative neglect of literacy needs by the international community, the White House Conference demonstrated the major impact that the commitment of one large country can have on improving the visibility of the global literacy challenge (UNESCO 3 August 2007).

Other initiatives created around the time of the United States return have not fared better. The LIFE program has barely begun and yet is immodestly presented as 'the United Nations' main multilateral response to the challenge of the Decade' (p.5). It states 'During 2006, responsibility for LIFE was transferred to the UNESCO Institute for Lifelong Learning (UIL), where the necessary networks with the countries involved are being built' (p.5). The Literacy Assessment and Monitoring Program (LAMP) that was intended to provide a robust although very costly means to assess literacy competencies suffered setbacks including the loss of its charismatic proponent, Dr. Scott Murray.

Further, while the document and the publicity about the First Lady Global Literacy Conference refer to 'success stories', 'replicable' programs and 'what works', they do a serious disservice to the cause of quality education for all. For sixty years UNESCO advocated for national governments and the international community to build the institutions needed for sustainable educational services. It has rarely had the resources or the commitment to conduct independent evaluations of such services. Nonetheless, it has not until now engaged solely in 'advocacy' that assumes any project or program can or should be replicated without an evaluation of its outcomes in its own cultural context. 
This superficial advocacy has not been lost on longstanding UNESCO partners with strong reading and writing pedagogy expertise. For example, the International Reading Association (IRA) circulated a set of concrete recommendations to encourage UNESCO to return to 'explicitly and directly focus on ensuring learners of all ages achieve high levels of competency in reading and writing [within] informed local policies, structures, institutions and the capacity-development of experts to design, deliver, and monitor high quality education.' (IRA April 2007). In 2009, the IRA also withdrew the funding for the international literacy prize it offered through UNESCO for many years, usually presented on 8 September, International Literacy Day.

Finally, the Secretariat's 'Draft decision' regarding its own progress in coordinating and implementing global and regional action for the UNLD states that the Executive Board is 'expressing its satisfaction with the activities undertaken, in particular the UNESCO Regional Conference in Support of Global Literacy which build on the White House Conference on Global Literacy....' .

If the UNESCO Secretariat no longer values minimal self-criticism in its own documents and does not recognise excessive politicisation rather than quality advocacy of the most legitimate of its education mandates - access by all to basic literacy - then I am deeply concerned that the millions of young people and adults the agency is intended to serve will indeed need to look elsewhere.

\section{What is needed to go forward? Another concept of 'reform'}

The following suggestions are not mine only. However, I consider them critical to re-establishing quality multilateral cooperation in UNESCO's fields of competence.

\section{For the staff of UNESCO:}

UNESCO needs the independent Ethics Office recommended by the IIC-OFFP established at UN Headquarters in New York in January 2006. That Office would have to be rigorously independent to ensure that the entire Secretariat be bound by the same code of conduct and professionalism. It would protect staff members from pressure by senior managers that leads to complicity in wrongdoing or fear of reprisal. Training in regulations is no alternative to such protection. As of April 2008, UNESCO only plans an ethics unit headed by a short-term individual to be 
recruited outside transparent procedures (Appointments of Limited Duration (ALD) contract). The Director-General surprisingly chose to discuss this matter in private session at the $179^{\text {th }}$ Executive Board (UNESCO 1 April 2008). Thus, he circumvented a possible well-informed Board debate on the merits of the existing Ethics Office in New York or the other models in UN bodies and the private sector. He neglected to inform the Board members that, if such an office were not in place at UNESCO by January 2008, all staff would have had the right to take questions and concerns to New York (UN 30 November 2007). Even the creation of a voluntary disclosure program, a pillar of all ethical public and private sector management, would still be at risk.

UNESCO needs an independent grievance handling system. It has an Appeals Board that only provides an advisory opinion to the DirectorGeneral on a staff member's attempt at recourse for an administrative decision deemed unjust. Further, the Board is poorly staffed (one chairperson and one full-time secretary) and its rotating members lack expertise in the complex regulations on which they need give an opinion. The Board only meets twice a year and is unable to give timely recommendations to the Director-General. His final decision is not bound by a time limit.

The recruitment, career development and re-deployment of all categories of personnel need to be handled by UNESCO's regulations. The irregular use of temporary contracts or ALD to carry out core UNESCO functions needs to be addressed urgently. While the latter experimental contracts were introduced to provide professional staff for short-term extra budgetary funded projects, they have been used abusively to replace regular professional staff members. Considerable confusion exists at this time as to who is actually responsible for what.

\section{For the governing bodies:}

The Executive Board was initially a group of intellectual leaders in UNESCO's fields of competence. In recent years it has become largely a smaller scale General Conference where members represent their countries' political positions. Some outstanding Board members combine vision, integrity and intellectual excellence. Others primarily represent official views of their country or regional grouping. It is difficult for bodies to reform themselves, but some members are looking at how to do just that. Two critical areas for scrutiny are: (a) the actual consequences of 'consensus' decision-making; and (b) the possibility of external evaluation of the Board's effectiveness in carrying out its governance function. Considerable backroom negotiation takes place in order to arrive at 'consensus decisions', frequently founded in political divergence. The Secretariat also works to orient 
decisions. Conflicting interests thus go under the carpet but are not really resolved. Thus, implementation of a consensus decision is not really facilitated. It might prove more constructive to allow voting to take place. For voting to be effective, however, the quality of the Board's governance function would also have to be tangibly improved. UNESCO's current External Auditors are probably the most independent in the Organization's history. They, along with the UN Joint Inspection Unit, might be tasked with such an evaluation, especially in light of the UN-wide reforms underway.

Member States have long given the Secretariat contradictory messages about what they expect. The latest Education Sector 'reform' was said to have been conceived at least in part to accelerate the 'decentralization' called for by certain countries. However, it is not clear that 'decentralization' is necessarily appropriate for an organisation whose structure is based on intergovernmental decision-making and whose mandate is intellectual cooperation. UNESCO has never been a field-based organisation like UNICEF or the UNDP (United Nations Development Programme). So, a critical look at its governing bodies would have to include scrutiny of its mandate.

\section{For the future of UNESCO in the UN system:}

UNESCO needs a more clearly defined mandate within the UN system. It was created for intellectual cooperation to promote peace and international understanding in the world through education, science and culture sixty years ago. There is now such a multiplicity of international actors in all these areas that only a highly professional complementary role can ensure its relevance today. I modestly suggest that in the field of education, basic and sustainable reading and writing skills for all be that priority mandate.

\section{A final suggestion to alleviate stress}

At this critical juncture for multilateralism, UN agencies need to be seen as relevant and useful. They have to demonstrate their 'comparative advantage' to all their Members. Generally, international aid and assistance are provided through bilateral mechanisms. The only future for multilateral intellectual cooperation agencies, such as UNESCO, seems to me to reside in clearly defining the fields within which they have a recognised history of consistent experience on which to draw, a proven willingness to evaluate critically that experience and the intellectual and ethical capacity to build on it. I have made this case in previous papers and I believe that I am in good company if I make it again. I consider that it is my responsibility to continue to do so in all the professional settings in which I find myself. 
This paper opened with a quotation from Henry David Thoreau, a $19^{\text {th }}$ century American philosopher whose thoughts accompanied me as a girl growing up in California and as an adult in UNESCO during the period of my country's absence and its return. Thoreau embodies the America that formed my values and which constitutes the best of what I sought to bring to multilateral cooperation. And I have hope for the future as a result.

i

A former UNESCO Director-General is said to have given the following advice to an incoming one when asked how to deal with the state of UNESCO on arrival. The advice was: (a) first blame your predecessor; (b) restructure the staff organigramme and if that fails, (c) resign.

ii There is a lack of clarity concerning responsibility for internal control. The Internal Oversight Service claims that it is the responsibility of senior management.

iii A single e-mail exchange between myself and the former Assistant Director-General for Education sums up my own experience: On 22 September 2006 after a silent and puzzling summer for colleagues following the 21 June reform announcement, Mr. Smith sent the following message to staff: 'Each of you should have now been informed about the workshops being held for each of the Headquarters' Divisions as part of the Education Sector reform. I would like to stress the importance of these workshops to each and every one of you, and I request that you do attend your division's session....'. I wrote back to him: 'Dear Mr. Smith, What about staff, such as myself, who are no longer considered members of any division according to your reform?'. Mr. Smith replied: 'Dear Ms. Limage, This is a workshop on implementing the reform for the future. As you are retiring within 5 weeks or so, I think it appropriate that you not attend.' 


\section{References}

Bush, George (2002) Speech to the United Nations General Assembly on 12 September2002,

http://www.whitehouse.gov.news/releses/2002/09/2020912-1.html

Cuevas, Juan (18 April 2007) Ecuador intervention to Plenary session, $176^{\text {th }}$

UNESCO Executive Board, Summary records in $176 \mathrm{EX} / \mathrm{SR}, 1-10$, p.73 at: http://www.unesco.org

Figaji, Brian (3 October 2006) Intervention by South Africa, in Plenary session, $175^{\text {th }}$ UNESCO Executive Board, Summary records of $175^{\text {th }}$ UNESCO Executive Board. http://www.unesco.org

Figaji, Brian (18 April 2007) Intervention by South Africa, in Plenary session, $176^{\text {th }}$ UNESCO Executive Board, Summary records in $176 \mathrm{EX} / \mathrm{SR}, 1-$ 10, p.91. http://www.unesco.org

Figaji, Brian (7 April 2008) Statement on behalf of Africa Group Members of the Executive Board, and South Africa's Statement: Executive Board, April 2008, pp 3-4, to be included in Summary records $179^{\text {th }}$ UNESCO Executive Board.

Graff, Harvey J. (1987), The Legacies of Literacy. Continuities and contradictions in Western culture and society, Indiana University Press, Bloomington.

Independent Inquiry Committee into the United Nations Oil-for-Food Programme. Under the Chairmanship of Volcker, Paul A. (September 2005) The Management of the United Nations Oil-for-Food Programme, Volume IV. Report of Investigation, United Nations Administration, Part II. http://www.iic-offp.org

International Reading Association (April 2007) Reading and Writing and Education for All: Strategy recommendations. Available from: http://www.reading.org

Jones, Phillip (1988) International Policies for Third World Education: UNESCO, Literacy and Development, Routledge, London.

Jones, Phillip with Coleman, Michael (2005) The United Nations and Education. Multilateralism, development and globalization, Routledge, London. 
Landymore, Peter (18 April 2007) United Kingdom intervention to Plenary Session, $176^{\text {ih }}$ UNESCO Executive Board Summary records 176 EX/SR. 1-10, p.70. http://www.unesco.org

Limage, Leslie (1987) The Right to Literacy, in Tarrow, Norma Bernstein (ed) Human Rights and Education, Pergamon Press, Oxford, pp 81100 .

Limage, Leslie (1993) A View from the International Literacy Year Secretariat, in Freebody, Peter and Welch, Anthony R (eds) Knowledge, Culture and Power: International Perspectives on Literacy as Policy and Practice, The Falmer Press, London, pp 23-34.

Limage, Leslie (1999). Literacy Practices and Literacy Policies: Where has UNESCO been and where might it be going? in International Journal of Educational Development, Vol 19, pp 75-89.

Limage, Leslie (2005a) The Growth of Literacy in Historic Perspective: Clarifying the role of formal school and adult learning opportunities, Background paper for the EFA Global Monitoring Report: Literacy for Life, 2006, available on EFA web-site and CD-ROM: http://www.unesco.org

Limage, Leslie (2005b) Literacy and Empowerment: Background and issues paper for the Working Group on Education for All session on literacy, July 2005. http://www.unesco.org

Limage, Leslie (2007) Organizational challenges to international cooperation for literacy in UNESCO, in special issue entitled 'Global Governance, Social Policy and Multilateral Education' of Comparative Education, (guest ed) Phillip Jones, Vol 43, No 3, pp 451-468.

Lynch, Colum (2007) US Fights off Bid to Punish UNESCO Official, Washington Post, 6 May. http://www.washingtonpost.com

Mukherjee, Bhaswati (3 October 2006) Intervention by India to the Plenary Session of the $175^{\text {th }}$ UNESCO Executive Board, Summary records of the $175^{\text {th }}$ Session, http://www.unesco.org.

Oliver, Louise (18 April 2007) Intervention of the United States to the Plenary Session of the $176^{\text {th }}$ UNESCO Executive Board, available in the Summary record of the $176^{\text {th }}$ UNESCO Executive Board at 176 EX/SR.1-10, p 96. http://www.unesco.org 
Oliver, Louise (8 April 2008) Executive Board Intervention-United States to the Plenary Session of the $179^{\text {th }}$ UNESCO Executive Board, U.S. Permanent Delegation to UNESCO web-site, http://www.unesco.usmission.gov

Ortigao, Ramalho (17 April 2007) Intervention on behalf of the European Union to the Plenary of the $176^{\text {th }}$ UNESCO Executive Board, Summary record of the $176^{\text {th }}$ UNESCO Executive Board in 176 EX/SR.1-10, p 14 - SR.2), http://www.unesco.org

Rausch, Susan (1995) The Quest for Universal Literacy: and who got what from International Literacy Year, Why and How?, unpublished doctoral dissertation, University of Massachusetts at Amherst, available from UMI Dissertation Services, Ann Arbor, Michigan.

Séguin, Phillipe (23 April 2007) Proposition D’intervention Devant la Commission Financière et Administrative, (in French), limited distribution, reported in summary form in Summary records of $176^{\text {th }}$ Executive Board 176 EX/SR. 1-10 in SR 9, paragraph 1.68, p 142. http://www.unesco.org

Séguin, Philippe (11April 2008) Intervention Devant la Commission Financière et Administrative et la Commission du Programme et des Relations Extérieures, (Intervention to present 179 EX/31, Parts, I, II, III, 7 March 2008. http://www.unesco.org)

Smith, Peter (12 March 2007) Letter of resignation to Director-General of UNESCO. Published on 14 March 2007 in article entitled Former CSUMB Chief Quits UNESCO Post on website of the KSBW Channel.com.

http://www.theksbwchannel.com/news/11254042/detail.html

Steensnaes, Einar (17 April 2007) Intervention of Norway to the Plenary Session of the $176^{\text {th }}$ UNESCO Executive Board, Summary record of the $176^{\text {h }}$ Executive Board. http://www.unesco.org

Thoreau, Henry David, (1854), Walden Ticknor \& Fields, Boston. 
UNESCO internal administrative communications:

DG/Note/00/11, 10 April 2000, (internal memo)

DG/Note/06/37, 12 July 2006 (internal memo)

DG/Note/06/38, 27 July 2006 (internal memo)

DG/Note/08/08, 4 March 2008 (internal memo)

UNESCO (29 July 2005a) 172 EX/10, United Nations Literacy Decade: Progress Report, 2004-2005, http://www.unesco.org

UNESCO (2005b) EFA Global Monitoring Report: Literacy for Life, 2006, UNESCO, Paris.

UNESCO (21 November 2005c) 172 EX/Decisions, Decisions adopted by the Executive Board at its 172 session, http://www.unesco.org.

UNESCO (June 2006a) United Nations Literacy Decade: Second Progress Report to the United Nations General Assembly for the period 20052006, (prepared by Leslie Limage on behalf of UNESCO), final document available on UNGA web-site, http://www.un.org

UNESCO (10 July 2006b) Education for All Global Action Plan: improving support to countries in achieving the EFA Goals. A basis for enhancing collective effort among the EFA convening agencies,

http://www.unesco.org

UNESCO (October 2006c) 175 EX/54 and Addendum, Draft decisions recommended by the Programme and External Relations Commissions, and $175 \mathrm{EX} / 55$, Draft Decisions recommended by the Finance and Administration Commission, UNESCO, Executive Board; $175^{\text {th }}$, 2006, http://www.unesco.org

UNESCO (2006d) EFA Global Monitoring Report 2007. Strong foundations. Early childhood care and education, UNESCO, Paris.

UNESCO (16 March 2007) 176 EX/39 Report by the External Auditor on the Procedures used to hire consultants for the restructuring of the Education Sector, Paris, UNESCO, http://www.unesco.org

UNESCO (16 April 2007) Director-General's written introduction to the General Debate of the Executive Board, 176 EX/INF.17 Rev, http://www.unesco.org 
UNESCO (17 April 2007) Draft Decision submitted by Algeria, Benin and India concerning Item 39: Report by the External Auditor on the procedures used to hire consultants for the restructuring of the Education Sector, 176 EX/FA/PX/DR.4, Limited distribution.

UNESCO (27 July 2007) Summary records (of the $176^{\text {th }}$ UNESCO Executive Board, 10-27 April 2007)' SR 1-10, http://www.unesco.org

UNESCO (3 August 2007) United Nations Literacy Decade (2003-2012): Progress Report 2006-2007, 177 EX/8, Paris, http://www.unesco.org

UNESCO (1 April 2008) Director-General's written introduction to the General Debate of the Executive Board, 179 EX/INF.8, http://www.unesco.org

UNESCO (24 March 2009) Progress made in the implementation of the recommendations of the External Auditor on audits already undertaken, 181 EX/34, Part II, Paris, http://www.unesco.org

UNESCO (8 July 2009) Final Communiqué. World Conference on Higher Education, ED.2009/CONF.402/2 Paris, available at http://www.unesco.org

United Nations Secretariat (30 November 2007) United Nations system-wide application of ethics: separately administered organs and programmes, Secretary-General's bulletin, ST/SGB/2007/11, http://www.un.org

United States State Department (24 April 2006) Press Release, 'Laura Bush Announces Global Literacy Conference', http://www.state.gov.

Vatasayan, Kapila. (18 April 2007) Intervention of India to the Plenary Session of the $176^{\text {th }}$ UNESCO Executive Board, Summary record of the $176^{\text {th }}$ Executive Board in $176 \mathrm{EX} / \mathrm{SSR} 1-10$, page 46,http://www.unesco.org

Vincent, David (2000) The Rise of Mass Literacy: Reading and Writing Modern Europe, Polity Press, London.

White House Fact Sheet (2002): United States Rejoins UNESCO, The White House web-site http://wwww.whitehouse.gov/news/releases/2002/09 